\title{
A novel method for rapid and quantitative detection of bisphenol $A$ in urine*
}

\author{
Aleksandra Rutkowska ${ }^{1,5}$, Aleksandra Olsson ${ }^{5}$, Jacek Namieśnik²†, Andrzej Milewicz ${ }^{3}$, \\ Jan K. Ludwicki ${ }^{4+}$, Paweł Struciński ${ }^{4}$ and Szymon Graczyk ${ }^{5}$
}

1'Institute of Nursing and Midwifery, Medical University of Gdańsk, Gdańsk, Poland; 2Department of Analytical Chemistry, Faculty of Chemistry, Gdańsk University of Technology, Gdańsk, Poland; 'Faculty of Natural Sciences and Technology, Karkonosze College in Jelenia Góra, Jelenia Góra, Poland; ${ }^{4}$ Department of Toxicology and Health Risk Assessment, National Institute of Public Health - National Institute of Hygiene, Warsaw, Poland; ${ }^{5}$ DetoxED Ltd, Gdańsk, Poland

Bisphenol A (BPA) is classified as an endocrine disruptor (ED) and can interact with a variety of hormone receptors leading to hormonal disruption and increased risk of numerous adverse health effects. Reducing human exposure to BPA is one of the main challenges of public health, as it is constantly present in the daily life. A low-cost and commonly applied method to enable determination of BPA in the patient's body has yet to be developed. Currently available techniques are expensive, time-consuming, and require access to highly equipped analytical chemistry laboratories. Here, we describe a fast and inexpensive engineered lateral flow assay of our design, to detect BPA in urine samples. This technology provides an opportunity to perform rapid biomonitoring. Addition of $\beta$-glucuronidase improves sensitivity of detection, as it releases free BPA from glucuronide complexes in the urine. This invention may become a commonly used analytical tools for lowering human exposure to BPA and probably to other EDs as well, and consequently it may be useful in decreasing the risk for several lifestyle diseases.

Key words: Bisphenol A, BPA, lateral flow assay, biomonitoring, endocrine disruptors

Received: 15 May, 2020; revised: 28 June, 2020; accepted: 28 June, 2020; available on-line: 30 July, 2020

⿶e-mail: aleksandra.rutkowska@gumed.edu.pl

†Deceased 14 April 2019

t†Retired 31 December 2018

*A patent for this invention has been granted by the Polish Patent Office on the $23^{\text {rd }}$ of April 2020.

Acknowledgements of Financial Support: This study was funded by resources of the Department of Analytical Chemistry, Gdańsk University of Technology, Poland

Abbreviations: BPA, bisphenol A; BSA, bovine serum albumin; CALUX, Chemically Activated Luciferase gene eXpression; ED, endocrine disruptor; EDC, endocrine disrupting chemical; ELISA, enzyme-linked immunosorbent assay; HPLC, high-performance liquid chromatography; GC, gas chromatography; LC-MS/MS, liquid chromatography combined with tandem mass spectrometry; LFA, lateral flow assay; LOD, limit of detection; PBS, Phosphate-Buffered Saline; PPARY2-CALUX, proliferator-activated receptor $\gamma 2$-Chemically Activated LUciferase gene eXpression; YES, Yeast Estrogen Screen

\section{INTRODUCTION}

Bisphenol A (BPA) is one of numerous endocrine disrupting chemicals (EDCs) or the so-called endocrine disruptors (EDs). The United States Environmental Protection Agency defines ED as an "exogenous agent that interferes with the production, release, transport, metabolism, binding, action, or elimination of natural hor- mones in the body responsible for the maintenance of homeostasis and the regulation of developmental processes" (Kavlock et al., 1996). Similarly to some steroid hormones, the structure of BPA contains aromatic rings; hence, it can interact with a variety of receptors for hormones and in consequence lead to hormonal disruption and increase the risk of various adverse health effects (Di Donato et al., 2017; Sifakis et al., 2017).

Widespread use of BPA-containing products, together with its ability to migrate from these materials, may explain the detectable levels of BPA in laboratory specimens that include serum, urine, amniotic fluid, milk, placenta, and neonatal blood (Vandenberg et al., 2010; Mendonca et al., 2014; Lee et al., 2018). Since humans are permanently exposed, there is an indisputable need for reducing the exposure to BPA (Gore et al., 2015). In addition, special attention should be given to pregnant women, as elevated concentrations of EDs in the amniotic fluid may disrupt the endocrine balance crucial for proper development of the gonads and can increase the risk of congenital anomalies of the urogenital tract (Braun, 2017; Pergialiotis et al., 2018). Permanent exposure may also alter epigenetic mechanisms, resulting in a higher risk of alterations in the offsprings even in the third generation (Mileva et al., 2014, Rutkowska et al., 2016; Ideta-Otsuka et al., 2017).

Despite the high relevance of biomonitoring and efforts aimed at reducing the exposure, no low-cost and easily applied method for rapid determination of BPA levels in a patient's body has been yet developed. Currently available methods for quantitative detection of EDs can be divided into three groups. The first consists of highly sensitive chromatographic techniques, such as gas chromatography (GC) or high-performance liquid chromatography (HPLC); often coupled with mass spectrometry, tandem mass spectrometry, or solid-phase microextraction (Sun et al., 2016; Jurek et al., 2017; Jurek et al., 2018; Owczarek et al, 2018; Dreolin et al., 2019).

The second group consists of bioassays used to determine the endocrine disruption potential of chemicals, their damaging effect on DNA (genotoxicity), and generation of oxidative stress. It includes various methods and the most commonly used are CALUX (Chemically Activated LUciferase gene eXpression), E-SCREEN, and YES (Yeast Estrogen Screen) (Park et al., 2008; Valitalo et al., 2016; Aneck-Hahn et al, 2018; Owczarek et al., 2018). The third group includes enzyme immunoassays used to visualize and quantify antigens, such as ELISA (enzymelinked immunosorbent assay) (Lee et al., 2017). 
All of the above-mentioned techniques require access to a fully equipped specialized laboratory and involve experienced chemists; hence, they are also expensive and time-consuming.

Another method that can be used for EDs determination is immunochromatography. Using it in a lateral flow rapid test makes it a low-cost and simple-to-use method that can easily be performed outside a laboratory, even by the patients themselves in the outpatients' clinics or at home.

Although analytical methods are being developed with greater simplicity and efficiency, higher selectivity and sensitivity, lower sample and solvent consumption, and greater automation routine, analysis of BPA levels in patients still poses great challenges (Sun et al., 2016; Dhanjai et al., 2018), especially since the serum/whole blood concentrations may often not predict the total body burden.

Here, we describe an engineered fast and inexpensive lateral flow assay (LFA) of our design for BPA detection in urine samples. This is a first powerful analytical tool that can be ready-to-use for biomonitoring without the need for an access to a laboratory and scientific equipment. Its unique advantage is the possibility to determine if the individual exposure to BPA is low, medium, or high, which may be of key importance from the public health perspective and human biological monitoring.

\section{MATERIALS AND METHODS}

Materials. Chemicals. Phosphate-Buffered Saline (PBS), Bovine Serum Albumin (BSA), $\beta$-glucuronidase enzyme, as well as the BPA standard and all LC chromatography reagents were ordered from Sigma Aldrich (USA). Innova Bioscience Latex Conjugation Kit was from Expedeon (formerly Innova BioScience, United Kingdom).

Antibodies. Rabbit polyclonal antibodies to BPA, and goat polyclonal antibodies to the rabbit antibodies were from Antibodies-online $\mathrm{GmbH}$ (Germany).

LFA constructions. All membranes: nitrocellulose, glass and cotton used in LFA were purchased from Ahlstrom-Munksjö (Finland). Color latex beads were from Expedeon (formerly Innova BioScience, United Kingdom).

Urine samples. Forty healthy volunteers (age range 2-40 years old) including males, females (also pregnant), and children had mid-stream urine samples collected into glass vials (previously autoclaved and sterilized) after an overnight fast. All samples were frozen at $-70^{\circ} \mathrm{C}$ until analysis.

Preparation of the lateral flow strips and test run. The lateral flow strips were created as a combination of different types of membranes, polyclonal antibodies to BPA - both adsorbed on membranes and on color carrier beads, and antibodies to the anti-BPA antibodies. A urine sample was being applied onto the sample pad (1) and then it flowed through an overlapping conjugate pad (2) onto which color carrier beads, coated with polyclonal antibodies to BPA, had been placed earlier. Further, the sample flowed through a membrane within which the urine sample and the color carrier beads, including those bound to the BPA present in the sample, can freely migrate (3). The membrane contains three indication areas covered with immobilized polyclonal antibodies to BPA (5) and one dedicated control area covered with immobilized polyclonal antibodies to antibodies to BPA, i.e. the control line (6). The first BPA indication area (the closest to the sample pad) detects a concentration that corresponds to low BPA exposure. Appearance of color in the first two areas indicates intermediate BPA exposure, whereas its appearance in the three consecutive BPA indication areas corresponds to high BPA exposure. A control area (the control line) contains antibodies to anti-BPA antibodies and the appearance of color in these lines upon application of the biological material indicates a proper test functioning. Migration of the sample and the unbound latex beads coated with antibodies stops at the termination area of the test (4) - the absorbent pad, where the adsorption of the sample occurs. The backing card, free from BPA and its derivatives (7), is an additional element that supports the membranes and facilitates the performance of the test outside a laboratory; however, it was skipped during laboratory validation.

A nitrocellulose membrane of $240-280 \mu \mathrm{m}$ in thickness was selected for the membrane of sample migration (3). Rabbit polyclonal antibodies to BPA, previously placed in PBS with $2 \%$ BSA, were applied onto the membrane. The amount of the antibodies corresponded to the detection of BPA concentrations of the maximum values of $2 \mathrm{ng} / \mathrm{mL}$ for the first, $3 \mathrm{ng} / \mathrm{mL}$ for the second, and $10 \mathrm{ng} / \mathrm{mL}$ for the third indication area. Goat polyclonal antibodies to rabbit antibodies to BPA were applied at the end of the membrane to form the control line of the test. A glass fiber membrane was selected for the sample pad (1) and the conjugate pad (2), whereas cotton fiber membrane was selected for the absorbent pad (4). The membrane was impregnated with PBS with $2 \%$ BSA and dried for 24 hours with subsequent application of $40 \mu \mathrm{L}$ of $1 \%$ solution of latex beads coated with rabbit antibodies to BPA (Expedeon, formerly Innova BioScience, United Kingdom).

Conjugation of color carries beads to antibodies. The process of conjugation was conducted by using the reagents and protocol according to the Innova Bioscience Latex Conjugation Kit manual. Briefly, the stock of polyclonal antibodies to BPA was diluted to $0.1 \mathrm{mg} /$ $\mathrm{mL}$ and then added to $400 \mathrm{~nm}$ blue latex nanoparticles. After 15 minutes of incubation at room temperature, the conjugation reaction was quenched. Then, the samples were centrifuged at $10000 \mathrm{rpm}$ for 6 minutes. The conjugation buffer was removed, and the pellet was resuspended in a buffer with the addition of $0.1 \%$ BSA.

Determination of BPA concentration in urine samples and estimation of individual exposure. A small volume of urine was poured into a container made from materials free from BPA and its derivatives. Then, $2 \mathrm{~mL}$ were transferred into a glass receptacle included in the test kit with a micropipette, up to the level marked with a horizontal line visible on the side wall of the receptacle. B-glucuronidase enzyme was sprayed onto the bottom and walls of the receptacle in order to catalyze hydrolysis of BPA glucuronide from urine; hence, to obtain the free form of BPA. The enzyme activity was at least 20000 units per gram, and it was added at a concentration of $20 \mu \mathrm{L}$ per $1 \mathrm{~mL}$ of urine. Afterwards, $100 \mu \mathrm{L}$ of the sample collected from the receptacle was applied on the sample pad and flowed to the area with immobilized color carrier beads where free BPA was bound by antibodies on the color latex beads. The urine sample, the unbound BPA, the beads with bound BPA, and the beads that did not bind BPA migrated onto the nitrocellulose membrane. According to the parameters of the membrane, the average migration rate was $150 \mathrm{~s} / 4 \mathrm{~cm}$. 


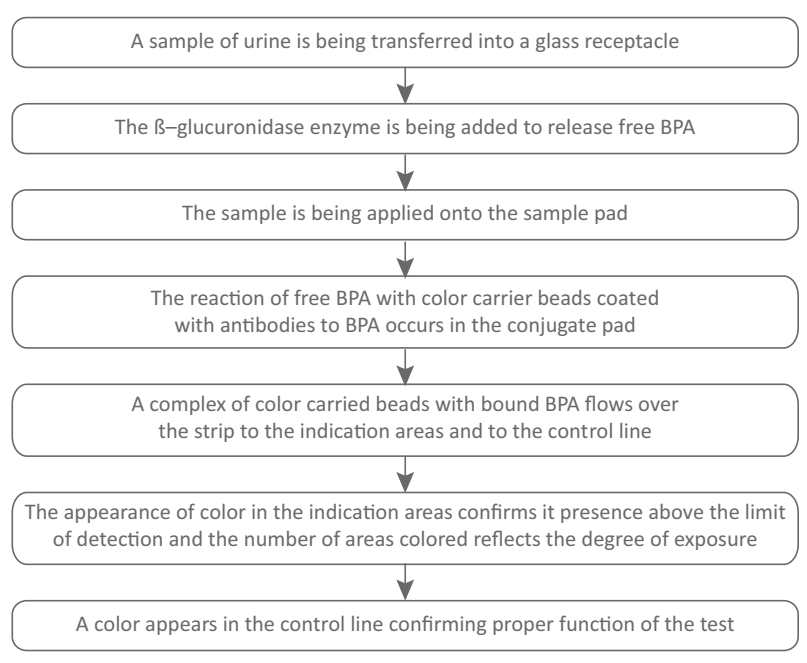

Figure 1. A scheme of using lateral flow assay for detection of BPA in urine samples.

A scheme of the procedure of urinary BPA determination using LFA is shown in Fig. 1.

The BPA quantification results using lateral flow strips were verified and validated using liquid chromatography-tandem mass spectrometry (LC-MS/MS) (Shimadzu
LCMS-8050, Japan). Each determination of BPA concentration in the urine sample was conducted in triplicate. The final results of BPA quantification in urine samples were expressed as an arithmetic mean of three measurements and the uncertainty of measurement; the procedure has been already published elsewhere (Wilczewska et al., 2016).

\section{RESULTS}

The colored indication area in LFA pointed to BPA detection in the urine sample. The concentrations of detected BPA sum up; thus, the appearance of color in one, two, or three BPA indication area(s), starting from the sample pad, corresponds to a level of up to $2 \mathrm{ng} /$ $\mathrm{mL}$ (low BPA concentration), up to $5 \mathrm{ng} / \mathrm{mL}$ (moderate BPA concentration), and up to $15 \mathrm{ng} / \mathrm{mL}$ (high BPA concentration), respectively. Proper functioning of the test (migration of carrier beads correctly coated with antibodies to BPA) was confirmed by the appearance of blue color in the control area. Figure 2 illustrates the principle of the strip test and exemplary results of the test for various BPA concentrations in the samples. The examples of different results for BPA concentration analysis in urine samples are illustrated in Fig. 3. The first strip (LFA 1) illustrates an example of the negative result of the test which means BPA concentration in the patient's urine was below LOD $(<1 \mathrm{ng} / \mathrm{mL})$. The sec-
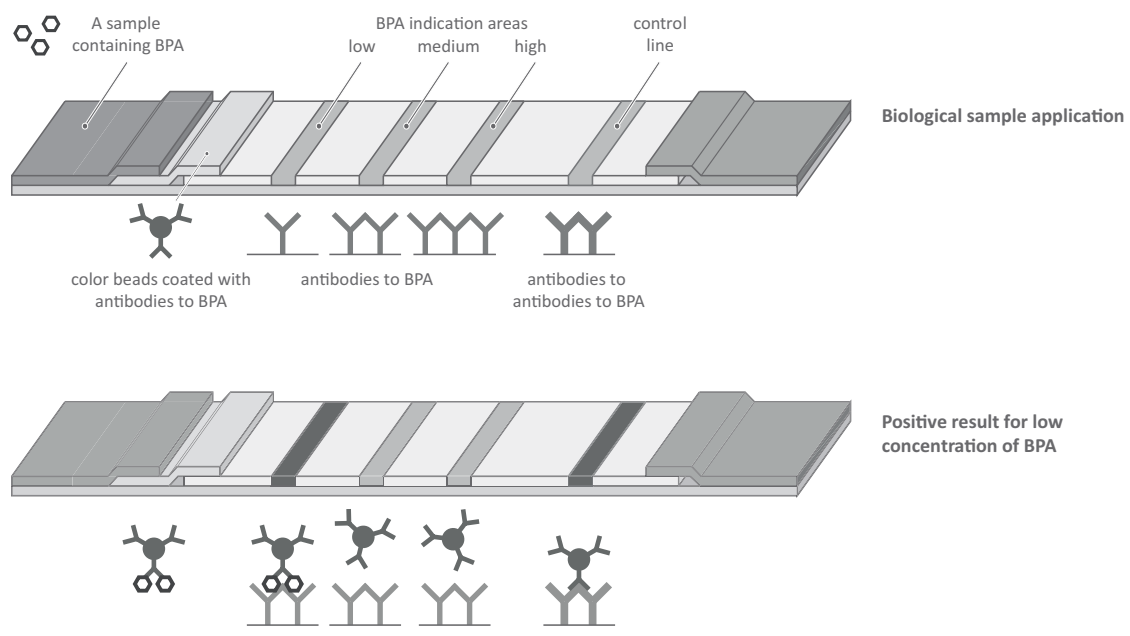

Positive result for low concentration of BPA

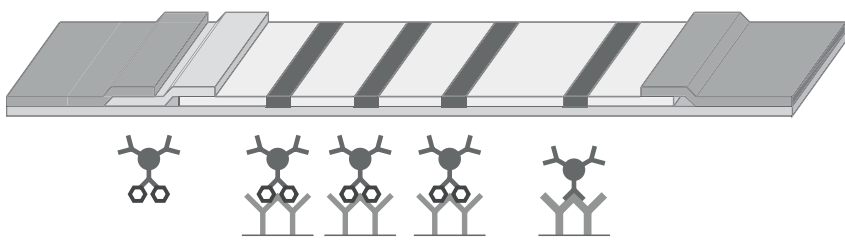

Positive result for high concentration of BPA

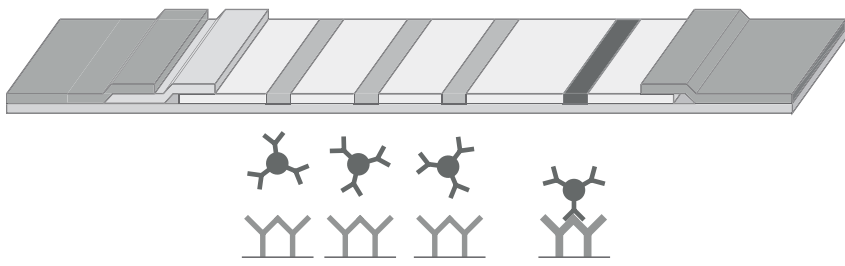

Negative result for BPA presence - concentration below LOD

Figure 2. Determination of BPA concentration in urine samples by lateral flow strips and estimation of different levels of individual exposure 


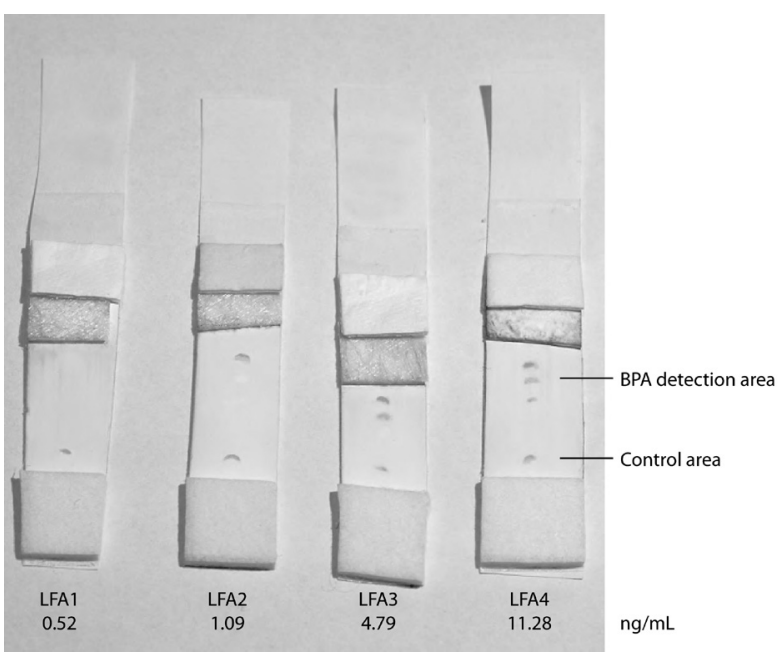

Figure 3. Examples of results of the lateral flow assay for different BPA concentrations in the urine samples, with results validated by LC-MS/MS.

Table 1. Results of chromatographic analysis of BPA concentration in urine samples without and with incubation with $\beta$-glucuronidase.

\begin{tabular}{lll}
\hline Sample & $\begin{array}{l}\text { BPA concentration witho- } \\
\text { ut } \beta \text {-glucuronidase } \\
(\mathrm{ng} / \mathrm{mL})\end{array}$ & $\begin{array}{l}\text { BPA concentration with } \\
\beta \text {-glucuronidase } \\
(\mathrm{ng} / \mathrm{mL})\end{array}$ \\
\hline 1. & $1.15 \pm 0.13$ & $10.22 \pm 1.5$ \\
\hline 2. & $0.19 \pm 0.02$ & $1.89 \pm 0.09$ \\
\hline 3. & $0.81 \pm 0.07$ & $1.35 \pm 0.08$ \\
\hline 4. & $<\mathrm{LOD}$ & $1.01 \pm 0.08$ \\
\hline 5. & $2.46 \pm 0.29$ & $4.79 \pm 0.36$ \\
\hline LOD & limit of detection & \\
\hline
\end{tabular}

ond strip (LFA 2), with one colored indication area illustrates low BPA concentration in the patient's urine, i.e. up to $2 \mathrm{ng} / \mathrm{mL}$. The result with two blue lines in the indication area of the third strip (LFA 3) demonstrates moderate BPA concentration in the sample, i.e. up to 5 $\mathrm{ng} / \mathrm{mL}$. The last strip (LFA 4) presents the possibility to evaluate high exposure to BPA and detection values up to $15 \mathrm{ng} / \mathrm{mL}$. The values of BPA concentrations presented in Fig. 3 were obtained for the same samples of urine using LC-MS/MS during assay validation to confirm the results of the assay.

Addition of $\beta$-glucuronidase to urine samples improved the LFA sensitivity. An example of chromatographic analysis results for the content of free BPA in the urine samples from healthy women (aged 21 to 24) before and after addition of $\beta$-glucuronidase (incubation with $20 \mu \mathrm{L}$ per $1 \mathrm{~mL}$ of urine) are summarized in Table 1. Table 2 presents concentrations of BPA in all urine samples measured via chromatography after addition of the enzyme, divided into levels with clear and unclear LFA results. LFA could give unclear/false results for the lowest concentrations of BPA detected in the samples. Although addition of $\beta$-glucuronidase has increased the level of free BPA in the sample and the sensitivity of the assay, there was still a risk for troubles in detection of the lowest BPA concentrations. Nevertheless, we believe that the uncertainty of some of the LFA results may be explained by manual application of antibodies on the membrane.
Table 2. BPA concentrations in the collected urine samples assessed with chromatography for validation.

\begin{tabular}{|c|c|}
\hline $\begin{array}{l}\text { Clear results for BPA detec- } \\
\text { tion }[\mathrm{ng} / \mathrm{mL}]\end{array}$ & $\begin{array}{l}\text { Uncertain /false results for BPA } \\
\text { detection in the samples [ng/ } \\
\mathrm{mL} \text { ] }\end{array}$ \\
\hline 10.22 & 1.05 \\
\hline 1.89 & 1.01 \\
\hline 1.35 & 1.6 \\
\hline 4.79 & 1.2 \\
\hline 3.3 & 2.6 \\
\hline \multicolumn{2}{|l|}{8.25} \\
\hline \multicolumn{2}{|l|}{2.14} \\
\hline \multicolumn{2}{|l|}{5.12} \\
\hline \multicolumn{2}{|l|}{5.2} \\
\hline \multicolumn{2}{|l|}{8.9} \\
\hline \multicolumn{2}{|l|}{4.2} \\
\hline \multicolumn{2}{|l|}{10.15} \\
\hline \multicolumn{2}{|l|}{3.79} \\
\hline \multicolumn{2}{|l|}{5.2} \\
\hline \multicolumn{2}{|l|}{3.19} \\
\hline \multicolumn{2}{|l|}{9.14} \\
\hline \multicolumn{2}{|l|}{4.15} \\
\hline \multicolumn{2}{|l|}{3.99} \\
\hline \multicolumn{2}{|l|}{12.4} \\
\hline \multicolumn{2}{|l|}{10.5} \\
\hline \multicolumn{2}{|l|}{2.19} \\
\hline \multicolumn{2}{|l|}{2.85} \\
\hline \multicolumn{2}{|l|}{1.43} \\
\hline \multicolumn{2}{|l|}{1.92} \\
\hline \multicolumn{2}{|l|}{3.8} \\
\hline \multicolumn{2}{|l|}{1.85} \\
\hline \multicolumn{2}{|l|}{1.16} \\
\hline \multicolumn{2}{|l|}{3.6} \\
\hline \multicolumn{2}{|l|}{4.09} \\
\hline \multicolumn{2}{|l|}{4.85} \\
\hline \multicolumn{2}{|l|}{1.41} \\
\hline \multicolumn{2}{|l|}{3.88} \\
\hline \multicolumn{2}{|l|}{3.5} \\
\hline 4.25 & \\
\hline 3.82 & \\
\hline 3.2 & \\
\hline 11.2 & \\
\hline 4.21 & \\
\hline 14.2 & \\
\hline
\end{tabular}

\section{DISCUSSION}

Constant human exposure to BPA may increase the risk of developing endocrine and metabolic disorders, obesity, diabetes mellitus, cardiovascular disease, infertility, and endocrine-dependent tumors in both, women and men (Street et al., 2018). In 2015 EFSA suggested 
Table 3. A comparison of advantages and drawbacks of the currently known analytical methods and the test that we developed.

\begin{tabular}{|c|c|c|c|c|c|}
\hline $\begin{array}{l}\text { Analytical } \\
\text { method }\end{array}$ & $\begin{array}{l}\text { Chromatographic analysis } \\
\text { (e.g. HPLC, GC) }\end{array}$ & $\begin{array}{l}\text { Bioassay (e.g. } \\
\text { CALUX, E-SCREEN, } \\
\text { YES) }\end{array}$ & $\begin{array}{l}\text { Immunoassay (e.g. } \\
\text { ELISA) }\end{array}$ & $\begin{array}{l}\text { Lateral flow as- } \\
\text { say and sensors }\end{array}$ & $\begin{array}{l}\text { Developed device } \\
\text { with addition of } \\
\beta \text {-glucuronidase }\end{array}$ \\
\hline Advantages & $\begin{array}{l}\text { Ultra-high sensitivity of } \\
\text { detection. } \\
\text { Possibility to measurecon- } \\
\text { centration of a specific } \\
\text { compound in a mixture. }\end{array}$ & $\begin{array}{l}\text { High sensitivity of } \\
\text { detection. } \\
\text { Ability to estimate } \\
\text { the endocrine } \\
\text { potential of a mi- } \\
\text { xture. }\end{array}$ & $\begin{array}{l}\text { High sensitivity of } \\
\text { detection. } \\
\text { Simple sample pre- } \\
\text { paration. } \\
\text { Rapidity. } \\
\text { Ease of operation of } \\
\text { portable devices. }\end{array}$ & $\begin{array}{l}\text { Simplicity. } \\
\text { Rapidity. } \\
\text { Cost-effective- } \\
\text { ness }\end{array}$ & $\begin{array}{l}\text { Simplicity. } \\
\text { Ready to use at home. } \\
\text { Rapidity. } \\
\text { Cost-effectiveness. } \\
\text { Higher sensitivity (free } \\
\text { BPA release from glu- } \\
\text { curonide complexes). } \\
\text { Possibility to estimate } \\
\text { BPA level exposure. }\end{array}$ \\
\hline Drawbacks & $\begin{array}{l}\text { Higher acquisition and } \\
\text { operational costs. } \\
\text { Highly specialized person- } \\
\text { nel and laboratory setting. } \\
\text { Long procedure of sample } \\
\text { preparation. } \\
\text { High cost of analysis. }\end{array}$ & $\begin{array}{l}\text { Cell-based assay } \\
\text { (analytical results } \\
\text { may depend on } \\
\text { the cells' condi- } \\
\text { tion). } \\
\text { Highly specialized } \\
\text { research equip- } \\
\text { ment. } \\
\text { Time-consuming } \\
\text { procedure. } \\
\text { High cost of ana- } \\
\text { lysis. }\end{array}$ & $\begin{array}{l}\text { Semi-quantitative. } \\
\text { Risk of false positives. } \\
\text { Specialized research } \\
\text { equipment. }\end{array}$ & $\begin{array}{l}\text { Lower sensiti- } \\
\text { vity. } \\
\text { Higher cross-re- } \\
\text { activity. } \\
\text { Risk of false } \\
\text { positives. }\end{array}$ & Semi-quantitative. \\
\hline Protocols & $\begin{array}{l}\text { Ultra-high-performance } \\
\text { liquid chromatography } \\
\text { tandem mass spectrometry } \\
\text { (UHPLC-MS/MS), LOD 0.13 } \\
\text { ng/mL, recoveries of 73.02- } \\
\text { 108.76\% (Yao et al., 2018). } \\
\text { Dispersive liquid-liquid } \\
\text { microextraction (DLLME) } \\
\text { and heart-cutting multidi- } \\
\text { mensional gas chromato- } \\
\text { graphy coupled to mass } \\
\text { spectrometry (MDGC/MS), } \\
\text { LOD 0.03 ng/mL (Cunha et } \\
\text { al., 2010). } \\
\text { Liquid chromatography- } \\
\text {-tandem mass spectrometry } \\
\text { (LC-MS/MS), LOD 0.4 ng/mL } \\
\text { (Chen et al., 2012). } \\
\text { Micro-QuEChERS (Quick, } \\
\text { Easy, Cheap, Effective, } \\
\text { Rugged and Safe) method } \\
\text { coupled to gas chromato- } \\
\text { graphy-mass spectrometry } \\
\text { (GCMS), LOD 0.13ng/mL, } \\
\text { recoveries >74\% (Correia-Sa } \\
\text { et al., 2018). } \\
\text { High performance liquid } \\
\text { chromatography tandem } \\
\text { mass spectrometry (HPLC- } \\
\text {-MS/MS), LOD 0.048 } \mu \text { g/L, } \\
\text { recoveries of } 82.2-88.9 \% \\
\text { (Wang et al., 2017). } \\
\text { Solid phase extraction and } \\
\text { liquid chromatography-tan- } \\
\text { dem mass spectrometry } \\
\text { (SPE-LC-MS/MS), LOD 0.10 } \\
\text { ng/mL, recoveries of } 80.1 \%- \\
108 \% \text { ( Jing et al., 2011). } \\
\text { Porous organogel materials } \\
\text { in combination with liquid } \\
\text { chromatography-tandem } \\
\text { mass spectrometry (LC- } \\
\text { MS-MS), LOD } 5 \text { ng/mL, } \\
\text { recovery >80\% (ter Halle et } \\
\text { al., 2015). }\end{array}$ & $\begin{array}{l}\text { PPARY2-CALUX } \\
\text { cells (Dusserre et } \\
\text { al., 2018). } \\
\text { E-SCREEN ( Soto et } \\
\text { al., 1995; Wu et al., } \\
\text { 2012). } \\
\text { Xenoscreen YES/ } \\
\text { YAS (Dvorakova et } \\
\text { al., 2016; Owczarek } \\
\text { et al., 2018). } \\
\text { Microtox (Owcza- } \\
\text { rek \& Kudlak et al., } \\
\text { 2018). }\end{array}$ & $\begin{array}{l}\text { Direct- and indirect } \\
\text { competitive enzyme- } \\
\text {-linked immunosor- } \\
\text { bent assay (ELISA), } \\
\text { LOD } 7.0 \mathrm{ng} / \mathrm{mL} \text { and } \\
0.08 \mathrm{ng} / \mathrm{mL} \text {, respecti- } \\
\text { vely (Yajing Lei et al., } \\
2013 \text { ) } \\
\text { Radioimmunoassay, } \\
\text { LOD } 0.2 \text { ng/mL (Har- } \\
\text { the et al., 2012). }\end{array}$ & $\begin{array}{l}\text { Aptamer-func- } \\
\text { tionalized ma- } \\
\text { gnetic nanopar- } \\
\text { ticles (AMNPs) } \\
\text { combined with } \\
\text { high perfor- } \\
\text { mance liquid } \\
\text { chromatography } \\
\text { (HPLC), LOD } 1.0 \\
\text { ng/mL, recove- } \\
\text { ries of } 90.8-93.8 \\
\% \text { (Su et al., } \\
2018) \text {. }\end{array}$ & \\
\hline
\end{tabular}

tenfold lowering of the Tolerable Daily Intake (TDI) for $\mathrm{BPA}$ - from $50 \mu \mathrm{g} / \mathrm{kg}$ of body weight/day to $4 \mu \mathrm{g} / \mathrm{kg}$ of body weight/day (establishing it as a temporary Tolerable Daily Intake - t-TDI) (Cwiek-Ludwicka, 2015; EFSA Panel on Food Contact Materials, 2015). A new EFSA assessment is planned to be ready by 2020 (EFSA's Panel on Food Contact Materials EaPAC, 2018).
Although BPA has been removed from most consumer products and human exposure should be dropping among the population in the future, it is still present in the daily lifestyle; thus, biomonitoring is of human and environmental benefit. Table 3 presents a comparison of advantages and drawbacks of the currently known and 
used analytical methods and of the test that we developed.

Lateral flow immunochromatographic assay may be an easy, and yet still valuable tool for determining the exposure to EDs, including BPA. To the best of our knowledge, there is no similar assay designed, nor was one patented (Mei et al., 2013; Maiolini et al., 2014; Sun et al., 2016).

The LFA technology presented here makes it possible to conduct a rapid diagnostic test without access to a central laboratory and it can be performed either by medical staff or by the patient at home. The addition of $\beta$-glucuronidase improves the sensitivity of detection, as it leads to a release of free BPA from glucuronide complexes in the urine. It is estimated that in the European Union only, exposure to EDs may substantially contribute to diseases and dysfunction across individual life courses, with costs of hundreds of billions of EUR per year. Without a doubt, its prevention can benefit the economy, but most importantly- the human life (Trasande et al., 2015). Thus, our invention may be a powerful and helpful analytical device for biomonitoring, as well as a concept to be used for preparing other LFAs for EDs detection; and therefore, it may help lowering the risk of some lifestyle diseases that have been linked with exposure to BPA (Gerona et al., 2020).

\section{Acknowledgements}

The authors are grateful to Prof. Błażej Kudłak, PhD Eng. from the Department of Analytical Chemistry, Gdańsk University of Technology, Poland, for his great contribution in the LFA development.

\section{Conflict of Interest}

None

\section{REFERENCES}

Aneck-Hahn NH, Van Zijl MC, Swart P, Truebody B, Genthe B, Charmier J, De Jager Ch (2018) Estrogenic activity, selected plasticizers and potential health risks associated with bottled water in South Africa. J Water Health 6: 253-262. https://doi.org/10.2166/ wh.2018.043

Braun JM (2017) Early-life exposure to EDCs: role in childhood obesity and neurodevelopment. Nat Rev Endocrinol 13: 161-173. https:// doi.org/10.1038/nrendo.2016.186

Chen M, Tao L, Collins EM, Austin C, Lu C (2012) Simultaneous determination of multiple phthalate metabolites and bisphenol-A in human urine by liquid chromatography-tandem mass spectrometry. J Chromatogr B Analyt Technol Biomed Life Sci 904: 73-80. https://doi. org/10.1016/j.jchromb.2012.07.022

Correia-Sa L, Norberto S, Delerue-Matos C, Calhau C, Domingues VF (2018) Micro-QuEChERS extraction coupled to GC-MS for a fast determination of Bisphenol A in human urine. I Chromatogr B Analyt Technol Biomed Life Sci 1072: 9-16. https://doi.org/10.1016/j. jchromb.2017.10.060

Cunha SC, Fernandes JO (2010) Quantification of free and total bisphenol A and bisphenol B in human urine by dispersive liquid-liquid microextraction (DLLME) and heart-cutting multidimensional gas chromatography-mass spectrometry (MD-GC/MS). Talanta 83: 117-125. https://doi.org/10.1016/j.talanta.2010.08.048

Cwiek-Ludwicka K (2015) Bisphenol A (BPA) in food contact materials - new scientific opinion from EFSA regarding public health risk. Rocr Panstw Zakl Hig 66: 299-307

Dhanjai, Sinha A, Wu L, Lu X, Chen J, Jain R (2018) Advances in sensing and biosensing of bisphenols: A review. Anal Chim Acta 998: 1-27. https://doi.org/10.1016/j.aca.2017.09.048

Di Donato M, Cernera G, Giovannelli P, Galasso G, Bilancio A, Migliaccio A, Castoria G (2017) Recent advances on bisphenol-A and endocrine disruptor effects on human prostate cancer. Mol Cell Endocrinol 457: 35-42. https://doi.org/10.1016/i.mce.2017.02.045

Dreolin N, Aznar M, Moret S, Nerin C (2019) Development and validation of a LC-MS/MS method for the analysis of bisphenol a in polyethylene terephthalate. Food Chem 274: 246-253. https://doi. org/10.1016/j.foodchem.2018.08.109
Dusserre C, Mollergues J, Lo Piparo E, Smiesko M, Marin-Kuan M, Schilter B, Fussell K (2018) Using bisphenol A and its analogs to address the feasibility and usefulness of the CALUX-PPARgamma assay to identify chemicals with obesogenic potential. Toxicol In $\mathrm{Vi}$ tro 53: 208-221. https://doi.org/10.1016/j.tiv.2018.08.008

Dvorakova M, Kejlova K, Bendova H, Rucki M, Kohout P, Vavrous A, Jírová D (2016) Alternative methods in vitro for screening of endocrine disruptors. Neuro Endocrinol Lett 37: 123-1231

EFSA Panel on Food Contact Materials E, Flavourings and Processing Aids (2015) Scientific Opinion on the risks to public health related to the presence of bisphenol A (BPA) in foodstuffs: Executive summary. EFS A J 13: 3978. https://doi.org/10.2903/j.efsa.2015.3978

EFSA (2015) Scientific Opinion on the risks to public health related to the presence of bisphenol A (BPA) in foodstuffs: Executive summary EFSA Panel on Food Contact Materials, Enzymes, Flavourings and Processing Aids (CEF). EFSA J 13: 3978. https://doi. org/10.2903/j.efsa.2015.3978

EFSA's Panel on Food Contact Materials EaPAC (2018) BPA update: working group to start reviewing new studies. www.efsa.europa.eu/ en/press/news/180904.

Gerona R, Vom Saal FS, Hunt PA (2020) BPA: have flawed analytical techniques compromised risk assessments? Lancet Diabetes Endocrinol 8: 11-13. https://doi.org/ 0.1016/S2213-8587(19)30381-X

Gore AC, Chappell VA, Fenton SE, Flaws JA, Nadal A, Prins GS, Toppari J, Zoeller JT (2015) Executive Summary to EDC-2: The Endocrine Society's Second Scientific Statement on Endocrine-Disrupting Chemicals. Endocrine Rev 36: 593-602. https://doi. org/10.1210/er.2015-1093

Harthe C, Rinaldi S, Achaintre D, de Ravel MR, Mappus E, Pugeat M, Déchaud H (2012) Bisphenol A-glucuronide measurement in urine samples. Talanta 100: 410-413. https://doi.org/10.1016/j.talanta.2012.07.099

Ideta-Otsuka M, Igarashi K, Narita M, Hirabayashi Y (2017) Epigenetic toxicity of environmental chemicals upon exposure during development - Bisphenol $\mathrm{A}$ and valproic acid may have epigenetic effects. Food Chem Toxicol 109: 812-816. https://doi.org/10.1016/j. fct.2017.09.014

Jing X, Bing S, Xiaoyan W, Xiaojie S, Yongning W (2011) A study on bisphenol A, nonylphenol, and octylphenol in human urine amples detected by SPE-UPLC-MS. Biomed Environ Sci 24: 40-46. https:// doi.org/10.3967/0895-3988.2011.01.005

Jurek A, Leitner E (2017) Analytical determination of bisphenol A (BPA) and bisphenol analogues in paper products by GC-MS/MS. Food Addit Contam Part A Chem Anal Control Expo Risk Assess 34: 1225-1238. https://doi.org/10.1080/19440049.2017.1319076

Jurek A, Leitner E (2018) Analytical determination of bisphenol A (BPA) and bisphenol analogues in paper products by LC-MS/MS. Food Addit Contam Part A Chem Anal Control Expo Risk Assess 35: 2256-2269. https://doi.org/10.1080/19440049.2018.1524157

Kavlock RJ, Daston GP, DeRosa C, Fenner-Crisp P, Gray LE, Kaattari S, Lucier G, Luster M, Mac MJ, Maczka C, Miller R, Moore J, Rolland R, Scott G, Sheehan DM, Sinks T, Tilson HA (1996) Research needs for the risk assessment of health and environmental effects of endocrine disruptors: a report of the U.S. EPA-sponsored workshop. Environ Health Perspect 4: 715-740. https://doi. org/10.1289/ehp.96104s4715

Lee JH, Yi SK, Kim SY, Kim JS, Son SA, Jeong SH, Kim JB (2017) Salivary bisphenol A levels and their association with composite resin restoration. Chemosphere 172: 46-51. https://doi.org/10.1016/j. chemosphere.2016.12.123

Lee J, Choi K, Park J, Moon HB, Choi G, Lee JJ, Suh E, Kim H-J, Eun S-H, Kim G-H, Cho GJ, Kim SK, Kim S, Kim SY, Kim S, Eom S, Choi S, Kim YD, Kim S (2018) Bisphenol A distribution in serum, urine, placenta, breast milk, and umbilical cord serum in a birth panel of mother-neonate pairs. Sci Total Environ 626: 1494 14501. https://doi.org/10.1016/j.scitotenv.2017.10.042

Maiolini E, Ferri E, Pitasi AL, Montoya A, Di Giovanni M, Errani E, Girotti S (2014) Bisphenol A determination in baby bottles by chemiluminescence enzyme-linked immunosorbent assay, lateral flow immunoassay and liquid chromatography tandem mass spectrometry. Analyst 139: 318-324. https://doi.org/10.1039/c3an00552f

Mei Z, Qu W, Deng Y, Chu H, Cao J, Xue F, Zheng L, El-Nezamic HS, Wu Y, Chen W (2013) One-step signal amplified lateral flow strip biosensor for ultrasensitive and on-site detection of bisphenol A (BPA) in aqueous samples. Biosens Bioelectron 49: 457-461. https:// doi.org/10.1016/j.bios.2013.06.006

Mendonca K, Hauser R, Calafat AM, Arbuckle TE, Duty SM (2014) Bisphenol A concentrations in maternal breast milk and infant urine. Int Arch Occup Environ Health 87: 13-20. https://doi.org/10.1007/ s00420-012-0834-9

Mileva G, Baker SL, Konkle AT, Bielajew C (2014) Bisphenol-A: epigenetic reprogramming and effects on reproduction and behavior. Int J Environ Res Public Health 11: 7537-7561. https://doi. org/10.3390/ijerph110707537

Owczarek K, Kubica P, Kudlak B, Rutkowska A, Konieczna A, Rachon D, Namiesnik J, Wasik A (2018) Determination of trace levels 
of eleven bisphenol A analogues in human blood serum by high performance liquid chromatography-tandem mass spectrometry. $S_{c i}$ Total Environ 628-629: 1362-1368. https://doi.org/10.1016/j.scitotenv.2018.02.148

Owczarek K, Kudlak B, Simeonov V, Mazerska Z, Namiesnik J (2018) Binary mixtures of selected bisphenols in the environment: their toxicity in relationship to individual constituents. Molecules 23: 3226. https://doi.org/10.3390/molecules23123226

Park JY, Lee BC, Ra JS, Lee J, Kim SD (2008) Effect of copper complexation on the estrogenic activities of endocrine-disrupting compounds using E-screen bioassay. Environ Toxicol Chem 27: 535-541. https://doi.org/10.1897/07-316

Pergialiotis V, Kotrogianni P, Christopoulos-Timogiannakis E, Koutaki D, Daskalakis G, Papantoniou N (2018) Bisphenol A and adverse pregnancy outcomes: a systematic review of the literature. J Matern Fetal Neonatal Med 31: 3320-3327. https://doi.org/10.1080/1476705 8.2017.1368076

Rutkowska AZ, Diamanti-Kandarakis E (2016) Polycystic ovary syndrome and environmental toxins. Fertil Steril 106: 948-958. https:// doi.org/10.1016/j.fertnstert.2016.08.031

Sifakis S, Androutsopoulos VP, Tsatsakis AM, Spandidos DA (2017) Human exposure to endocrine disrupting chemicals: effects on the male and female reproductive systems. Environ Toxicol Pharmacol 51: 56-70. https://doi.org/10.1016/j.etap.2017.02.024

Soto AM, Sonnenschein C, Chung KL, Fernandez MF, Olea N, Serrano FO (1995) The E-SCREEN assay as a tool to identify estrogens: an update on estrogenic environmental pollutants. Environ Health Perspect 7: 113-122. https://doi.org/10.1289/ehp.95103s7113

Street ME, Angelini S, Bernasconi S, Burgio E, Cassio A, Catellani C, Cirillo F, Deodati A, Fabbrizi E, Fanos V, Gargano G, Grossi G, Lughetti L, Lazzeroni P, Mantovani A, Migliore L, Palanza P, Panzica G, Papini AM, Parmigiani S, Predieri B, Sartori Ch, Tridenti G, Amarri S (2018) Current Knowledge on Endocrine Disrupting Chemicals (EDCs) from Animal Biology to Humans, from Pregnancy to Adulthood: Highlights from a National Italian Meeting. Int J Mol Sci 19: 1646. https://doi.org/10.3390/ijms19061647

Su Y, Shao C, Huang X, Qi J, Ge R, Guan H, Lin Z (2018) Extraction and detection of bisphenol $\mathrm{A}$ in human serum and urine by aptamer-functionalized magnetic nanoparticles. Anal Bioanal Chem 410 1885-1891. https://doi.org/10.1007/s00216-017-0801-0

Sun F, Kang L, Xiang X, Li H, Luo X, Luo R, Lu Ch, Peng X (2016) Recent advances and progress in the detection of bisphenol A. Anal
Bioanal Chem 408: 6913-6927. https://doi.org/10.1007/s00216-0169791-6

ter Halle A, Claparols C, Garrigues JC, Franceschi-Messant S, Perez E (2015) Development of an extraction method based on new porous organogel materials coupled with liquid chromatography-mass spectrometry for the rapid quantification of bisphenol $\mathrm{A}$ in urine. $J$ Chromatogr A 1414: 1-9. https://doi.org/10.1016/j.chroma.2015.07.046

Trasande L, Zoeller RT, Hass U, Kortenkamp A, Grandjean P, Myers JP, DiGangi J, Bellanger M, Hauser R, Legler J, Skakkebaek NE, Heindel JJ (2015) Estimating burden and disease costs of exposure to endocrine-disrupting chemicals in the European union. I Clin Endocrinol Metab 100: 1245-1255. https://doi.org/10.1210/jc.2014-4324

Valitalo P, Perkola N, Seiler TB, Sillanpaa M, Kuckelkorn J, Mikola A, Hollert H, Schultz E (2016) Estrogenic activity in Finnish municipal wastewater effluents. Water Res 88: 740-749. https://doi. org/10.1016/j.watres.2015.10.056

Vandenberg LN, Chahoud I, Heindel JJ, Padmanabhan V, Paumgartten FJ, Schoenfelder G (2010) Urinary, circulating, and tissue biomonitoring studies indicate widespread exposure to bisphenol A. Environ Health Perspect 118: 1055-1070. https://doi.org/10.1289/ ehp.0901716

Wang H, Liu L, Eqani S, Shen H. (2017) Infant exposure to bisphenol a can be quantitatively assessed by a simply improved high-performance liquid chromatography-tandem mass-spectrometry method. Anal Sci 33: 777-781. https://doi.org/10.2116/analsci.33.777

Wilczewska K, Namiesnik J, Wasik A (2016) Troubleshooting of the determination of bisphenol $\mathrm{A}$ at ultra-trace levels by liquid chromatography and tandem mass spectrometry. Anal Bioanal Chem 408: 1009-1013. https://doi.org/10.1007/s00216-015-9215-z

Wu S, Wei X, Jiang J, Shang L, Hao W (2012) Effects of bisphenol A on the proliferation and cell cycle of HBL-100 cells. Food Chem Toxicol 50: 3100-3105. https://doi.org/10.1016/j.fct.2012.06.029

Lei Y, Fang L, Akash MSH, Liu Z, Shid W, Chen S (2013) Development and comparison of two competitive ELISAs for the detection of bisphenol A in human urine. Anal Methods 5: 6106-6113. https://doi.org/10.1039/C3AY41023D

Yao Y, Shao Y, Zhan M, Zou X, Qu W, Zhou Y (2018) Rapid and sensitive determination of nine bisphenol analogues, three amphenicol antibiotics, and six phthalate metabolites in human urine samples using UHPLC-MS/MS. Anal Bioanal Chem 410: 3871-3883. https://doi.org/10.1007/s00216-018-1062-2 